ARTICLE

Received 17 Jul 2015 | Accepted 20 Nov 2015 | Published 8 Jan $2016 \quad$ DOl: 10.1038/ncomms10254 OPEN

\title{
Three-dimensional controlled growth of monodisperse sub-50 nm heterogeneous nanocrystals
}

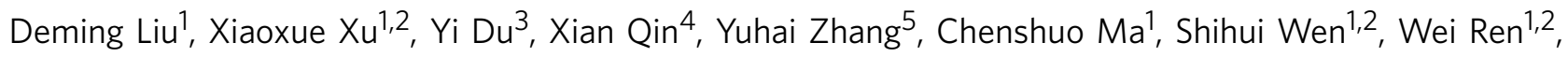
Ewa M. Goldys ${ }^{1}$, James A. Piper ${ }^{1}$, Shixue Dou ${ }^{3}$, Xiaogang Liu ${ }^{4,5} \&$ Dayong Jin ${ }^{1,2}$

The ultimate frontier in nanomaterials engineering is to realize their composition control with atomic scale precision to enable fabrication of nanoparticles with desirable size, shape and surface properties. Such control becomes even more useful when growing hybrid nanocrystals designed to integrate multiple functionalities. Here we report achieving such degree of control in a family of rare-earth-doped nanomaterials. We experimentally verify the co-existence and different roles of oleate anions $\left(\mathrm{OA}^{-}\right)$and molecules $(\mathrm{OAH})$ in the crystal formation. We identify that the control over the ratio of $\mathrm{OA}^{-}$to $\mathrm{OAH}$ can be used to directionally inhibit, promote or etch the crystallographic facets of the nanoparticles. This control enables selective grafting of shells with complex morphologies grown over nanocrystal cores, thus allowing the fabrication of a diverse library of monodisperse sub-50 nm nanoparticles. With such programmable additive and subtractive engineering a variety of three-dimensional shapes can be implemented using a bottom-up scalable approach.

\footnotetext{
${ }^{1}$ Laboratory of Advanced Cytometry, ARC Centre of Excellence for Nanoscale BioPhotonics, Department of Physics and Astronomy, Macquarie University, Sydney, New South Wales 2109, Australia. ${ }^{2}$ Faculty of Science, Institute for Biomedical Materials and Devices, University of Technology Sydney, New South Wales 2007, Australia. ${ }^{3}$ Institute for Superconducting and Electronic Materials, Innovation Campus, University of Wollongong, New South Wales 2522 Australia. ${ }^{4}$ Institute of Materials Research and Engineering, 3 Research Link, Singapore 117602, Singapore. ${ }^{5}$ Department of Chemistry, National University of Singapore, 3 Science Drive 3, Singapore 117543, Singapore. Correspondence and requests for materials should be addressed to X.L.

(email: chmlx@nus.edu.sg) or to D.J. (email: dayong.jin@uts.edu.au).
} 
$\mathrm{N}$ anocrystal engineering, design and fabrication of nanocrystals with desirable size, shape ${ }^{1-6}$, surface properties ${ }^{7}$ and composition ${ }^{8,9}$ is attracting growing interest due to its essential role in fundamental research and commercial relevance. Rare-earth-doped upconversion nanocrystals have recently emerged as the new generation of functional nanomaterials, because they exhibit exceptional optical, magnetic and chemical properties underpinning their diverse applications. In particular, alkaline rare-earth fluoride $\left(\mathrm{AREF}_{4}\right)$ nanocrystals ${ }^{10-12}$, including hexagonal-phase $\beta-\mathrm{NaYF}_{4}, \quad \beta$ $\mathrm{NaGdF}_{4}, \beta-\mathrm{NaNdF}_{4}$ or $\beta-\mathrm{NaLuF}_{4}$ are used in full-colour displays $^{12,13}$, photovoltaics ${ }^{14}$, security inks ${ }^{15}$, forensic science ${ }^{16}$, autofluorescence-free biomolecular sensing ${ }^{17-19}$, multimodal in vivo bio-imaging (fluorescence, magnetic resonance imaging, X-ray, SPECT and so on. $)^{20}$ and theranostics ${ }^{17,21-23}$. A trial-anderror approach is frequently used to produce nanoparticles with spherical, rod-like or other shapes ${ }^{24-26}$ by varying dopant concentrations and/or constituent materials ${ }^{27}$, reaction time and temperature ${ }^{28-31}$. This random sampling of vast, multidimensional parameter space, needs to be done rationally, with proper understanding of the underpinning growth mechanisms.

Here we find that oleate anions $\left(\mathrm{OA}^{-}\right)$, the dissociated form of oleic acid molecules $(\mathrm{OAH})$, have variable, dynamic roles in mediating the growth of $\mathrm{AREF}_{4}$ nanocrystals. This allows us to introduce a molecular approach to tailoring the shape and composition of $\mathrm{AREF}_{4}$ nanocrystals. This new method is based on a selective epitaxial core-shell growth process in the presence of oleic acid, commonly used as a surfactant during the synthesis of $\beta-\mathrm{AREF}_{4}$ nanocrystals ${ }^{32}$. Drawing inspiration from the recently discovered co-existence of oleic acid molecules $(\mathrm{OAH})$ and their dissociated form, oleic acid ions $\left(\mathrm{OA}^{-}\right)$in the binary systems of $\mathrm{PbS}^{33}$ and $\mathrm{PbSe}$ nanocrystals ${ }^{34}$, we hypothesize that the change in the ratio of $\mathrm{OA}^{-}$to $\mathrm{OAH}$ could influence the interaction of these ligands with the particle surface and hence the resulting morphology. Our computational modelling (Fig. 1, Supplementary Figs 1-6, Supplementary Notes 1 and 2 and Supplementary Table 1) and experimental results (Figs 2-4, Supplementary Figs 7-35, Supplementary Tables 2 and 3 and Supplementary Notes 3-18) demonstrate that the preferential affinity of $\mathrm{OAH}$ and $\mathrm{OA}^{-}$to different crystalline facets dictates the formation of nanocrystals of different shape. Importantly, we demonstrate that the precise control over the shell thickness and the particle shape can be achieved by deliberately switching the passivation, additive and subtractive roles of these surfactants.

\section{Results}

Computational modelling. To quantify the surface coordination chemistry between $\beta-\mathrm{NaYF}_{4}$ surface and $\mathrm{OAH}$ and $\mathrm{OA}^{-}$ligands, we performed first-principles calculations based on density functional theory using CASTEP (CAmbridge Serial Total Energy Package $)^{35}$. As shown in Fig. $1 \mathrm{~b}$ and Supplementary Fig. 1, we treated the (001) and (100) planes of the $\beta-\mathrm{NaYF}_{4}$ nanocrystals terminated with specific atomic arrangement as the most stable facets according to the calculated surface energies. Considering that the oxygen moiety in the ligands has a strong binding affinity to $\mathrm{Y}^{3+}$ ions at the particle surface ${ }^{36}$, we modelled the interactions between the $\mathrm{OAH}$ and $\mathrm{OA}^{-}$molecules and the $\mathrm{Y}^{3+}$ ions under a number of conditions, such as different adsorption configurations (Supplementary Figs 2 and 3 and Supplementary Note 1), ligand chain length and ligand coverage (Supplementary Figs 4 and 5 and Supplementary Note 2). The key conclusion from these simulations is that $\mathrm{OA}^{-}$preferentially binds to $\mathrm{RE}^{3+}$ ions exposed on the (100) facet of the hexagonal fluoride nanocrystal, with a much higher binding energy $(-35.4 \mathrm{eV})$ than on the $(001)$ facet $(-21.8 \mathrm{eV})$. It should be noted that the $\mathrm{OAH}$ molecule binds with a higher probability to the (001) facet than the (100) facet and has relatively small binding energies of $-9.4 \mathrm{eV}$ and $-4.6 \mathrm{eV}$, respectively, on each of these facets (Supplementary Table 1). Our charge analysis (Supplementary Fig. 6) further indicates that such selective binding is attributed to the difference in the atomic arrangements of these two facets (Fig. 1b), giving rise to different charge transfer paths between the ligands and the surface ions. a

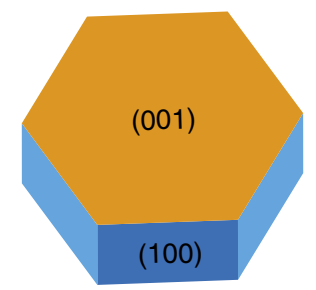

b

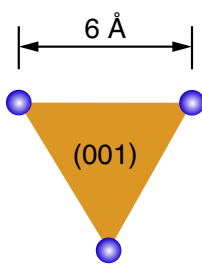

$\mathrm{Y}^{3+}$

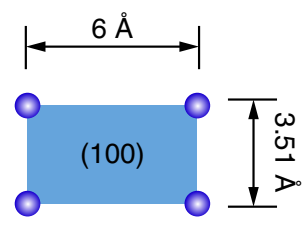

Binding energy $\left(\mathrm{meV} \AA^{-2}\right)$

\begin{tabular}{|c|c|c|}
\hline & $(001)$ & $(100)$ \\
\hline $\mathrm{OA}^{-}$ & -21.8 & -35.4 \\
\hline $\mathrm{OAH}$ & -9.4 & -4.6 \\
\hline
\end{tabular}

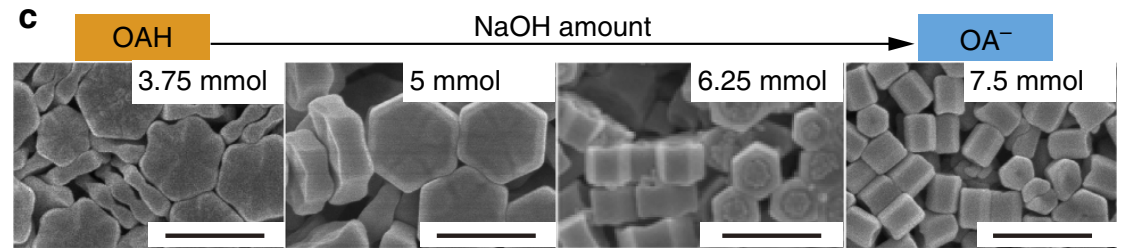

Figure 1 | Preferred molecular bonding models of $\mathbf{O A}^{-}$and $\mathbf{O A H}$. (a) The schematic shape of a $\beta-\mathrm{NaYF}_{4}$ nanocrystal chosen as the core for directional epitaxial growth in this work. The hexagonal cylinder consists of the (001) facets at the ends and identical (100) and (010) facets around the cylinder sides. (b) The $\mathrm{Y}^{3+}$ arrangements and binding energies (see insert table) of OAH and $\mathrm{OA}^{-}$on the most stable (001) and (100) facets. The $\mathrm{Y}^{3+}$ atoms form equilateral triangles with a length of $6 \AA$ in the relaxed (001) surface, while rectangles are observed in the (100) surface with a shorter length of 3.51 or $3.69 \AA$; (c) SEM characterization of submicron-sized nanocrystals synthesized using the hydrothermal route (detailed synthesis is included in the method; scale bar, $500 \mathrm{~nm}$ ). 


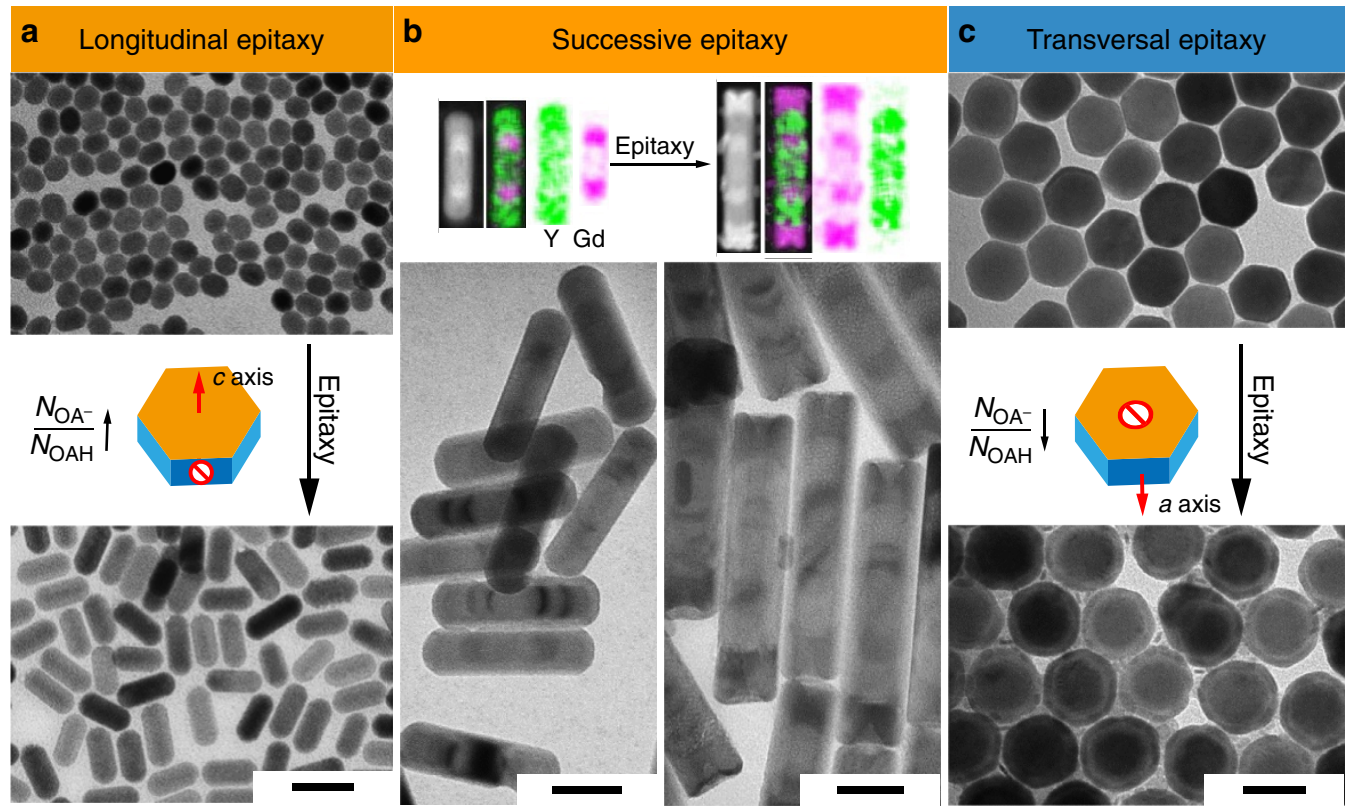

Figure 2 | Physical characterization of epitaxial growth of $\mathbf{N a R e F}_{\mathbf{4}} \mathbf{N C s}$. (a) NaYF 4 core and homogenous NaYF $\mathrm{NCs}_{4}$ after epitaxial growth of NaYF 4 in longitudinal direction with $0.5 \mathrm{mmol} \mathrm{NaOH}$ and $9.5 \mathrm{mmol} \mathrm{OA}$ at $310^{\circ} \mathrm{C}$ for $1 \mathrm{~h}$; (b) five-section and seven-section 'bamboo-shaped' $\mathrm{NaYF} 4 / \mathrm{NaGdF}_{4} \mathrm{NRs}$ formed by successive heterogeneous growth of periodical shells of $\mathrm{NaGdF}_{4}-\mathrm{NaYF}_{4}$ and $\mathrm{NaGdF}_{4}-\mathrm{NaYF}_{4}-\mathrm{NaGdF}_{4}$ onto $\mathrm{NaYF}_{4}$ core in the longitudinal direction, with $0.5 \mathrm{mmol} \mathrm{NaOH}$ and $0.4 \mathrm{mmol} \mathrm{KOH}$ and $9.5 \mathrm{mmol} O A$ at $310^{\circ} \mathrm{C}$. Upper part of the panel shows elemental mapping of $\mathrm{Y}$ and $\mathrm{Gd}$; (c) $\mathrm{NaYF}_{4}$ core and heterogeneous $\mathrm{NaYF}_{4} / \mathrm{NaGdF}_{4} \mathrm{NCs}$ after epitaxial growth of $\mathrm{NaGdF}_{4}$ in the transversal direction with $0.15 \mathrm{mmol} \mathrm{NaOH}$ and $19 \mathrm{mmol} \mathrm{OA}$ at $290^{\circ} \mathrm{C}$ for $3 \mathrm{~h}$; the dimensions of individual nanocrystal were analysed statistically and included in the Supplementary Figs 10, 20-24. Scale bar, 50 nm.

Controlled epitaxial growth direction. The binding preferences of $\mathrm{OAH}$ and $\mathrm{OA}^{-}$molecules to different facets were first used to induce longitudinal epitaxial growth. We demonstrated (Fig. 1c) that sub-micrometre-sized $\mathrm{NaYF}_{4}$ crystals of different aspect ratios could be prepared by tuning the concentration ratio of $\mathrm{OA}^{-}$to $\mathrm{OAH}$ in the hydrothermal synthesis system. As shown in Supplementary Fig. 7, higher concentrations of $\mathrm{OA}^{-}$encourage epitaxial growth along a longitudinal direction. A similar effect was observed in the synthesis of sub- $50 \mathrm{~nm} \mathrm{NaYF} 4$ nanoparticles prepared by a co-precipitation method. Figure $2 \mathrm{a}, \mathrm{b}$ show that high concentration of $\mathrm{NaOH}$ leads to longitudinally grown nanoparticles because of a large concentration of passivating $\mathrm{OA}^{-}$ions on the (100) facets (Supplementary Figs 8-10). The zeta potential of $+20 \mathrm{mV}$ for $\mathrm{NaYF}_{4}$ nanocrystals after the removal of ligands (Supplementary Fig. 11) shows that the $\mathrm{RE}^{3+}$ cations are more abundant on the crystal surfaces than the $\mathrm{F}^{-}$ ions. We further systemically studied other possible factors that could influence the epitaxial shell growth (experimental details in Supplementary Methods), including the reaction temperature (Supplementary Fig. 12 and Supplementary Note 3), the oleic acid concentration (Supplementary Fig. 13 and Supplementary Note 4), the $\mathrm{F}^{-}$ion concentration (Supplementary Fig. 14 and Supplementary Note 5) and the $\mathrm{Na}^{+}$concentration (Supplementary Fig. 15 and Supplementary Note 6). From these results, we confirm that the ratio of $\mathrm{OA}^{-} / \mathrm{OAH}$ is a key factor that determines the epitaxial shell growth direction. However other parameters also have an effect on the growth speed or can change the $\mathrm{OA}^{-} / \mathrm{OAH}$ ratio that indirectly affects the direction of growth. To rule out the effect of $\mathrm{OH}^{-}$on longitudinal growth, we added sodium oleate as the sodium source instead of hydroxide and identical results were obtained (Supplementary Fig. 16 and Supplementary Note 7). Supplementary Figures 17 and 18 further confirm that high ratio of $\mathrm{OA}^{-} / \mathrm{OAH}$ directs longitudinal deposition of heterogeneous shells $\left(\mathrm{NaGdF}_{4}\right)$ on the end surfaces of $\mathrm{NaYF}_{4}$ core. Interestingly, subtractive growth (dissolution) is observed from their side (100) surfaces. This results in concurrent decrease of the core width from 26 to $18 \mathrm{~nm}$, thus producing dumbbell-shaped nanocrystals (Supplementary Note 8).

Moreover, we found that the addition of $\mathrm{KOH}$ further accelerates longitudinal growth rate (Supplementary Fig. 19 and Supplementary Note 9) due to a higher dissociation constant of $\mathrm{KOH}$ than $\mathrm{NaOH}$, which increases the dissociation of $\mathrm{OAH}$ producing more $\mathrm{OA}^{-}$. With the aid of $\mathrm{KOH}$, heterogeneous 'bamboo-shaped' nanorods (NRs) with sharp edges were formed in a stepwise manner with a length of up to $173 \mathrm{~nm}$ (Fig. 2b, Supplementary Fig. 21 and Supplementary Note 10). The interesting one-dimension architecture of 'bamboo-shaped' NRs suggests that integrated multiple functionalities can be built. Thus our new platform enables rational design and facile synthesis of multiple sections of rare-earth-doped heterogeneous materials and investigation of their interactions and functions within a single integrated rod. We were also able to induce transversal epitaxial growth by increasing the amount of $\mathrm{OAH}$ and reducing the amount of $\mathrm{NaOH}$. At a reaction temperature of $290^{\circ} \mathrm{C}$, the transversal growth was observed and $\mathrm{NaGdF}_{4}$ rings of 7 -nm-thick around the $\mathrm{NaYF}_{4}$ cores formed without a measurable change in the longitudinal direction (Fig. 2c, Supplementary Figs 23 and 24 and Supplementary Note 11). Notably, the dissolution of the (100) facets of the cores took place as well, and the width of the core was, again, reduced from 49 to $30 \mathrm{~nm}$ at both ends. The observed dissolution always occurred on the (100) facets in both cases of longitudinal and transversal growth. This is consistent with the strong chelating character of $\mathrm{OA}^{-}$on the (100) facet, and with the fact that $\mathrm{NaYF}_{4}$ is dissolved faster than $\mathrm{NaGdF}_{4}$ because $\mathrm{NaYF}_{4}$ is comparably less energetically stable ${ }^{12}$. To shed more light on this issue, we provided more evidence in the Supplementary Fig. 25 and Supplementary Note 12 to show that the dissolution of core is caused by the thermal stability difference 

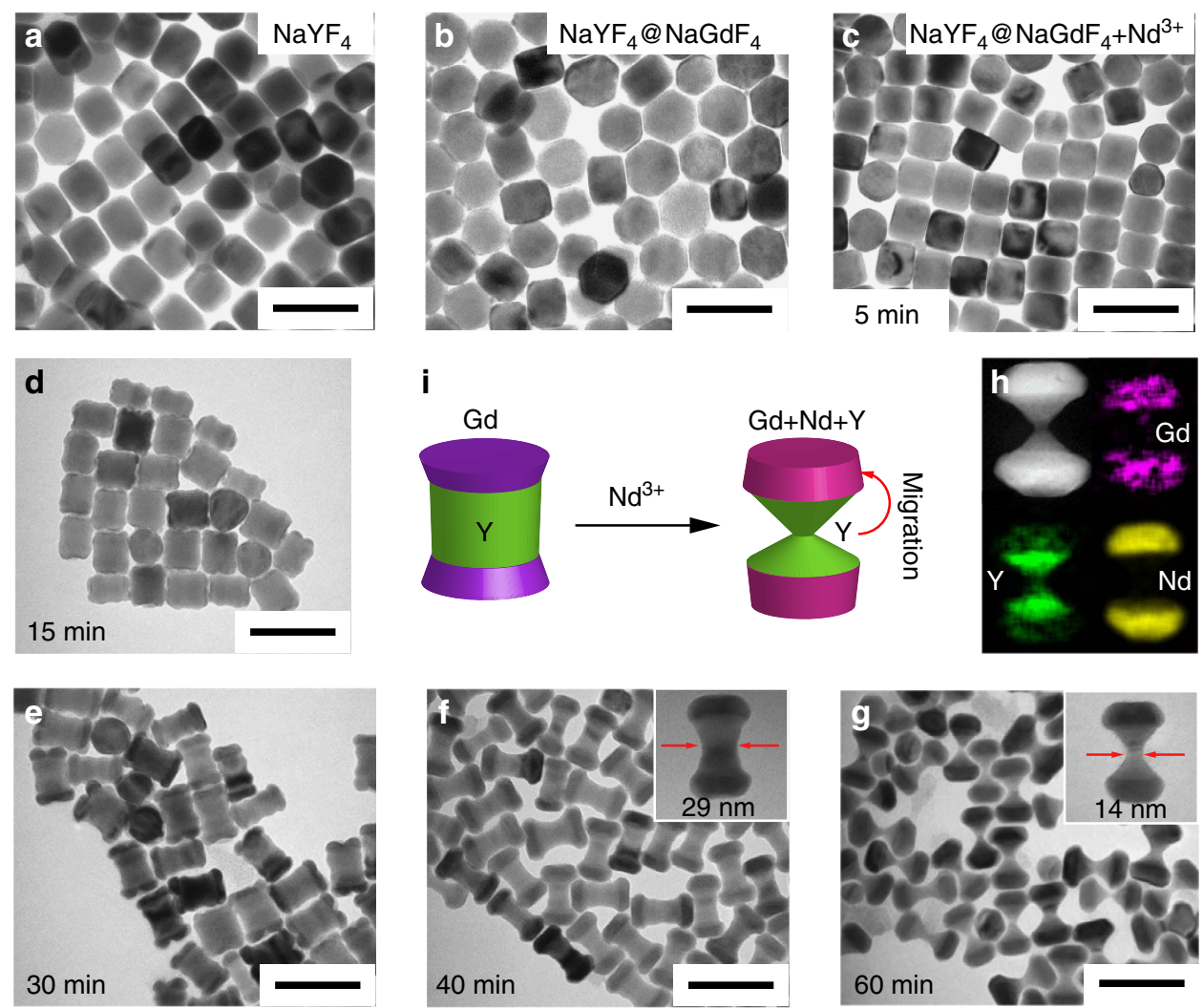

Figure 3 | Evolution of morphology and composition in migration growth. $(\mathbf{a}, \mathbf{b}) \mathrm{NaGdF}_{4}$ growth along the longitudinal direction onto the ends of the $\mathrm{NaYF}_{4}$ core; (c) transmission electron microscope image of the sample stopped 5 min after reacting with $\mathrm{NaGdF} / \mathrm{NaYF}_{4}$ nanocrystals in the presence of $\mathrm{Na}^{+}, \mathrm{K}^{+}, \mathrm{Nd}^{3+}, \mathrm{OA}^{-}$and in the absence of $\mathrm{F}^{-}$at $310^{\circ} \mathrm{C}$, dissolution occurs first; $(\mathbf{d}-\mathbf{g})$ real-time monitoring of the epitaxial growth of $\mathrm{NaNdF}_{4}$ along the longitudinal direction onto $\mathrm{NaYF}_{4}-\mathrm{NaGdF}_{4}$ nanocrystals, involving the dissolution of $\mathrm{NaYF}_{4}$ and $\mathrm{NaGdF}_{4}$ from the transversal surfaces of the crystal and their subsequent re-growth onto the $\mathrm{NaNdF}_{4}$ nanocrystals in the presence of $\mathrm{Na}^{+}, \mathrm{K}^{+}, \mathrm{Nd}^{3+}, \mathrm{OA}^{-}$and absence of $\mathrm{F}^{-}$ions at $310^{\circ} \mathrm{C}$. (h) HAADF-STEM image with elemental mapping results of the samples stopped after 60 min of reaction to confirm the distributions of $\mathrm{Y}^{3+}, \mathrm{Gd}^{3+}, \mathrm{Nd}^{3+}$ ions within a single $\mathrm{NaYF}_{4} / \mathrm{NaGdF}_{4} / \mathrm{NaNdF}_{4}$ nanocrystal. (i) schematic processes of dissolution of $\mathrm{NaYF}_{4} / \mathrm{NaGdF}_{4}$ and the sequent epitaxial growth of $\mathrm{NaNdF}_{4}$ in the longitudinal direction and the migration growth of $\mathrm{F}^{-}, \mathrm{Y}^{3+}$ and $\mathrm{Gd}^{3+}$ ions (scale bar, $100 \mathrm{~nm}$ ).

between core and shell materials in presence of $\mathrm{OA}^{-}$which leads to higher binding strength on the side surfaces. By comparing growth of $\mathrm{NaTbF}_{4}$ as shell or $\mathrm{NaYbF}_{4}$ as shell on a $\mathrm{NaYF}_{4}$ core (Supplementary Fig. 25), we demonstrate that the dissolution of the core requires the shell materials to have higher thermal stability than the core material. Larger difference of thermal stability between core and shell result in a higher dissolution rate.

Controlled migration growth. By combining the approaches of longitudinal and transversal growth and selective dissolution with consideration of lattice mismatch (Supplementary Tables 2 and 3 ), we synthesized a variety of three-dimensional (3D) hybrid nanostructures (Supplementary Figs 26-34). Figure 3 shows a typical example of real-time evolution of morphology and composition of the $\mathrm{NaYF}_{4} / \mathrm{NaGdF}_{4} / \mathrm{NaNdF}_{4} \mathrm{NCs}$, including the dissolution process of the $\mathrm{NaYF}_{4} / \mathrm{NaGdF}_{4}$ nanocrystals and subsequent longitudinal growth of $\mathrm{NaNdF}_{4}$. The dissolution of $\mathrm{NaYF}_{4} / \mathrm{NaGdF}_{4}$ is initiated by the $\mathrm{OA}^{-}$adsorbed on the surface of the nanocrystals. The concomitant depletion of dissolved $\mathrm{F}^{-}$ ions used for longitudinal growth of $\mathrm{NaNdF}_{4}$ in the presence of high concentration of $\mathrm{OA}^{-}$facilitates the dissolution of $\mathrm{NaYF}_{4} / \mathrm{NaGdF}_{4}$ nanocrystals and this, in turn, promotes longitudinal growth of $\mathrm{NaNdF}_{4}$. Following the dissolution of the $\mathrm{Y}^{3+}$ and $\mathrm{Gd}^{3+}$ ions from the surface of $\mathrm{NaYF}_{4}-\mathrm{NaGdF}_{4}$ nanocrystals, these ions then participate in the epitaxial growth of $\mathrm{NaNdF}_{4}$ nanocrystals, as evidenced by the elemental mapping (Fig. 3h). Moreover, our real-time sampling transmission electron microscope data further confirmed the underpinning mechanism (Fig. 3a-g, Supplementary Figs 26-28). The size of nanocrystal core decreased significantly in the first $5 \mathrm{~min}$, indicating that the dissolution rate of the nanocrystals is faster than their growth rate. After $15 \mathrm{~min}$, new material started to form at the top and at the bottom ends of the core with simultaneous decrease of the nanocrystal core width. This observation rules out 'surface mobility' ('atom diffusion') as the possible driving force behind the formation of the final shell, otherwise it is expected that the dissolution of $\mathrm{NaYF}_{4}$ and growth of $\mathrm{NaNdF}_{4}$ would occur at the same time. The only mechanism which explains the shape of this nanocrystal is that the absence of $\mathrm{F}^{-}$source in the reaction solution at its beginning prevents growth of $\mathrm{NaNdY}_{4}$ until the concentration of released $\mathrm{F}^{-}$source exceeds a certain threshold.

Our control experiments (Supplementary Fig. 29 and Supplementary Note 15) further support the mechanism of $\mathrm{OA}^{-}$-induced dissolution in which a firm bonding of the surfactant $\mathrm{OA}^{-}$to the surface $\mathrm{RE}^{3+}$ cations is the main factor responsible for the removal of the surface crystalline layers (experimental details in Supplementary Methods). As shown in Supplementary Fig. 29, we applied transversal growth approach to first grow a layer of $\mathrm{NaGdF}_{4}$ on the side surfaces of $\mathrm{NaYF}_{4}$ core. We see that smaller mismatch of $\mathrm{NaGdF}_{4}$ versus $\mathrm{NaNdF}_{4}$ compared with the $\mathrm{NaYF}_{4}$ versus $\mathrm{NaNdF}_{4}$ fails to direct the transversal migration growth of the $\mathrm{NaNdF}_{4}$ on the side surfaces of $\mathrm{NaGdF}_{4}$. Instead, dissolution occurs in the first $10 \mathrm{~min}$ of the reaction (Supplementary Fig. 29a,b) and both dissolution from 


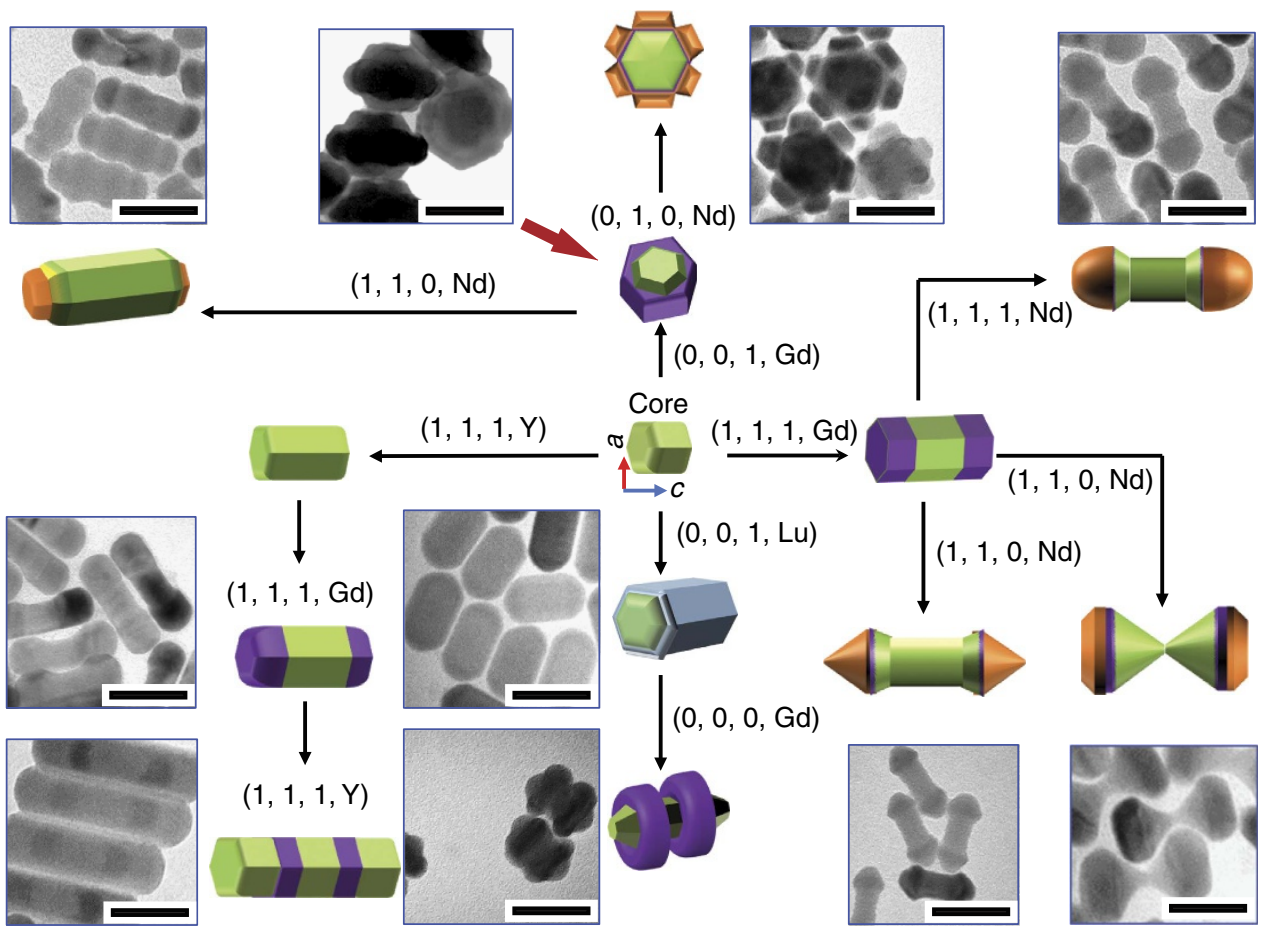

Figure 4 | Programmable routes for fabricating 3D nano-architectures. The four digital condition codes $(R, T, F$ and $R E)$ represent different reaction conditions where: $R=0$, represents a low ratio of $\mathrm{OA}^{-} / \mathrm{OAH} ; R=1$, represents a high ratio of $\mathrm{OA}^{-} / \mathrm{OAH}^{-} T=0$, where the temperature is at $290^{\circ} \mathrm{C}$; $T=1$, where the temperature is at $310^{\circ} \mathrm{C} ; F=0$, which designates the absence of an $F^{-}$ion source; $F=1$, indicates the presence of an $F^{-}$ion source; $\mathrm{RE}=\mathrm{Y}$, with a rare earth $\mathrm{Y}^{3+}$ ion source; $\mathrm{RE}=\mathrm{Gd}$, with $\mathrm{Gd}^{3+}$ ion source; $\mathrm{RE}=\mathrm{Lu}$, with a $\mathrm{Lu}^{3+}$ source; $\mathrm{RE}=\mathrm{Nd}$, with $\mathrm{Nd}^{3+}$ source. By combining these different growth processes into a synthesis procedure, a variety of complex $\mathrm{NaREF}_{4}$ nanostructures are fabricated as shown in the transmission electron microscope images, including hourglass shaped $\mathrm{NaYF}_{4} / \mathrm{NaGdF}_{4} / \mathrm{NaNdF}_{4}$ nanocrystals, $\mathrm{NaYF}_{4} / \mathrm{NaGdF}_{4} / \mathrm{NaNdF}_{4}$ nano-flowers, $\mathrm{NaYF}_{4} / \mathrm{NaLuF}_{4}$ co-axial nano-cylinders, $\mathrm{NaYF}_{4} / \mathrm{NaLuF}_{4} / \mathrm{NaGdF}_{4}$ nanoscale spins with double rings, and $\mathrm{NaYF}_{4} / \mathrm{NaGdF}_{4} / \mathrm{NaNdF}_{4}$ nano-dumbbells with smooth or sharp ends (scale bar, $50 \mathrm{~nm}$ ).

the side surfaces and epitaxial growth of $\mathrm{NaNdF}_{4}$ on the end surfaces of $\mathrm{NaGdF}_{4} / \mathrm{NaYF}_{4}$ cores result in a thinner and longer nanocrystal.

Guided by the principle that the ratio of $\mathrm{OA}^{-} / \mathrm{OAH}$ controls the direction of epitaxial shell growth, we further demonstrated (as shown in Supplementary Fig. 30 and Supplementary Note 16) that a low ratio of $\mathrm{OA}^{-} / \mathrm{OAH}$ at a lower temperature directs the migration growth along transverse direction. This enables the formation of heterogeneous $\mathrm{NaYF}_{4} / \mathrm{NaGdF}_{4} / \mathrm{NaNdF}_{4}$ nanocrystals in the shape of a flower, although in this case the dissolution process on the side surfaces of nanocrystals is much less efficient because there are too few $\mathrm{OA}^{-}$ligands bound to $\mathrm{RE}^{3+}$ cations on the (100) facet. Two additional experiments (Supplementary Note 17) demonstrate that well established parameters, such as reagent concentration, can be further applied to fine-tune our programmable protocols for other types of heterogeneous nanocrystals. During the formation of hourglassshaped nanocrystals, the decrease in the amount of $\mathrm{Nd}^{3}+$ source is found to hinder the migration growth process and yield sharper tips (Supplementary Fig. 31), whereas a supply of additional $\mathrm{F}^{-}$ ions in the reaction increases the diameter of dumbbell ends with round tips (Supplementary Fig. 32). Such level of fine tuning to grow progressively sharper tips may suggest future rational methods, for example to optimize tip-sensitive physical and biochemical properties of NRs.

Figure 4 shows an array of heterogeneous $\mathrm{NaREF}_{4}$ nanostructures synthesized by carrying out specific sequences of longitudinal, transversal growth, selective dissolution and directional migration growth of epitaxial shells in the presence of various $\mathrm{OA}^{-} / \mathrm{OAH}$ ratios. To the best of our knowledge, these sub-50 nm nanoparticles are the smallest $3 \mathrm{D}$ objects prepared by a bottom-up additive and subtractive process. To illustrate the application of this novel method we designed and synthesized multifunctional $\mathrm{NaYF}_{4} / \mathrm{NaLuF}_{4} / \mathrm{NaGdF}_{4}$ heterogeneous nanocrystals with two $\mathrm{NaGdF}_{4}$ rings on a $\mathrm{NaLuF}_{4} / \mathrm{NaYF}_{4}$ NRs (Supplementary Figs 33 and 34 and Supplementary Note 18). The hexagonal-phase $\mathrm{NaYF}_{4}$ nanocrystal is an efficient luminescence upconversion material ${ }^{37}$. The addition of $\mathrm{NaLuF}_{4}$ enables X-ray computed tomography ${ }^{38}$, whereas using $\mathrm{NaGdF}_{4}$ enables magnetic resonance imaging 39 . To the best of our knowledge, this work presents the first controlled fabrication of sub-50 nm 3D shaped heterogeneous nanocrystals logically programmed by the combinational approaches of $\mathrm{OA}^{-}$-assisted longitudinal growth, transversal growth and selective crystalline facet dissolution with consideration of crystallographic mismatch rates.

\section{Discussion}

The nanoscale engineering capability presented in this work enables quantitative studies which are virtually impossible by conventional approaches. We anticipate that optical properties of these nanostructures can be designed to precisely promote or inhibit inter-particle energy transfer. Similarly, magnetic properties may be optimized to enhance magnetic resonance imaging by correlating the morphology with the surface distribution of magnetic signals. In addition, such hybrid nanomaterials may be used as a platform for transporting biologically important molecules across cell membranes. Furthermore, access to a new library of precisely controlled shapes of nanoparticles provide a novel approach for the targeted delivery in nanomedicine where optimized morphologies of these nanoscale molecular carriers will yield greater efficiencies. This 
process could be further facilitated by harnessing the anisotropic properties of different types of nanoparticles that permit diverse surface functionalizations and multi-modal bio-conjugations. The concept presented in this work may further advance our current capabilities of nanoscale programmable and reproducible engineering of new classes of heterogeneous materials in scalable quantities. Our findings may lead to a new class of multifunctional nanomaterials and provide the groundwork for developing previously unforeseen applications of nanoparticles with complex programmable shapes and surface properties.

\section{Methods}

Hydrothermal synthesis of $\mathrm{NaYF}_{\mathbf{4}}$ crystal. The $\beta-\mathrm{NaYF}_{4}$ disks were synthesized via a slightly modified hydrothermal reaction. In a typical experiment, $\mathrm{NaOH}$ $(3.75 \mathrm{mmol})$ was first dissolved into $1.5 \mathrm{~mL}$ of double distilled water, followed by the addition of $\mathrm{OA}(7.5 \mathrm{mmol})$ and ethanol $(2.5 \mathrm{~mL})$ while undergoing vigorous stirring. Thereafter, an aqueous solution of $\mathrm{NaF}(0.5 \mathrm{M} ; 2 \mathrm{~mL})$ was added to form a turbid mixture. Subsequently, a $1.2 \mathrm{~mL}$ aqueous solution of $\mathrm{YCl}_{3}\left(\mathrm{Yb}^{3+} / \mathrm{Tm}^{3+}\right.$ $=10 / 0.5 \mathrm{~mol} \% ; 0.2 \mathrm{M}$ ) was added and the solution was stirred for $20 \mathrm{~min}$. The resulting mixture was then transferred into a $14 \mathrm{~mL}$ Teflon-lined autoclave and heated to $220^{\circ} \mathrm{C}$ and the temperature maintained for $12 \mathrm{~h}$. After cooling down to room temperature, the reaction product was isolated by centrifugation and washed with ethanol. In this work, different amounts of $\mathrm{NaOH}$ were added to adjust the ratio of $\mathrm{OA}^{-} / \mathrm{OAH}$ by its reaction with $\mathrm{OAH}$ to form $\mathrm{OA}^{-}$.

$\mathrm{NaYF}_{4}$ nanocrystal cores. In a typical procedure, $4 \mathrm{ml}$ of methanol solution of $\mathrm{YCl}_{3}(2.0 \mathrm{mmol})$ was magnetically mixed with $\mathrm{OA}(38 \mathrm{mmol})$ and ODE $(93 \mathrm{mmol})$ in a 100-ml three-neck round-bottom flask. The mixture was then degassed under the Ar flow and then heated to $150^{\circ} \mathrm{C}$ for $30 \mathrm{~min}$ to form a clear solution, before cooling to room temperature. $15 \mathrm{ml}$ of methanol solution containing $\mathrm{NH}_{4} \mathrm{~F}$ $(8 \mathrm{mmol})$ and $\mathrm{NaOH}(5 \mathrm{mmol})$ was added to the solution of $\mathrm{YCl}_{3}$ in OA and ODE and stirred for $60 \mathrm{~min}$. The mixture solution was slowly heated to $110^{\circ} \mathrm{C}$ and kept at $110^{\circ} \mathrm{C}$ for $30 \mathrm{~min}$ to completely remove methanol and any residual water. The mixture solution was then quickly heated to the reaction temperature of $300^{\circ} \mathrm{C}$ and aged for $1 \mathrm{~h}$. After the solution was left to cool down to room temperature, ethanol was added to precipitate the nanocrystals. The product was washed with cyclohexane, ethanol and methanol for at least 4 times, before the final $\mathrm{NaYF}_{4}$ nanocrystals were re-dispersed in $10 \mathrm{ml}$ cyclohexane in preparation for their further use.

Longitudinal growth of $\mathbf{N a Y F}_{\mathbf{4}} \mathbf{N R s} . \mathrm{YCl}_{3}(0.2 \mathrm{mmol})$ in $1 \mathrm{ml}$ methanol solution was magnetically mixed with $\mathrm{OA}(9.5 \mathrm{mmol})$ and $\mathrm{ODE}(25 \mathrm{mmol})$ in a $50-\mathrm{ml}$ threeneck round-bottom flask. The mixture was degassed under Ar flow and heated to $150^{\circ} \mathrm{C}$ for $30 \mathrm{~min}$ to form a clear solution, and then cooled to room temperature. Methanol solution $(5 \mathrm{ml})$ containing $\mathrm{NH}_{4} \mathrm{~F}(0.8 \mathrm{mmol})$ and $\mathrm{NaOH}(0.5 \mathrm{mmol})$ was added and stirred for $60 \mathrm{~min}$. The solution was slowly heated to $110^{\circ} \mathrm{C}$ and kept at $110^{\circ} \mathrm{C}$ for $30 \mathrm{~min}$ to completely remove methanol and residual water. The solution was then injected with $0.2 \mathrm{mmol} \mathrm{NaYF}_{4}$ of nanocrystals in cyclohexane and the mixture kept at $110^{\circ} \mathrm{C}$ for another $10 \mathrm{~min}$ to evaporate the cyclohexane. Then, the reaction mixture was quickly heated to $310^{\circ} \mathrm{C}$ and aged for $1 \mathrm{~h}$.

$\mathbf{N a G d F}_{\mathbf{4}} / \mathrm{NaYF}_{\mathbf{4}}$ nano-dumbbells. $\mathrm{GdCl}_{3}(0.2 \mathrm{mmol})$ in $1 \mathrm{ml}$ methanol solution was magnetically mixed with $\mathrm{OA}(9.5 \mathrm{mmol})$ and ODE $(25 \mathrm{mmol})$ in a $50-\mathrm{ml}$ threeneck round-bottom flask. The mixture was degassed under an $\mathrm{Ar}$ flow and heated to $150^{\circ} \mathrm{C}$ for $30 \mathrm{~min}$ to form a clear solution, and then cooled to room temperature. Methanol solution $(4 \mathrm{ml})$ containing $\mathrm{NH}_{4} \mathrm{~F}(0.8 \mathrm{mmol})$ and $\mathrm{NaOH}(0.5 \mathrm{mmol})$ was added to the $\mathrm{OA}$ and $\mathrm{ODE}$ solution and stirred for $60 \mathrm{~min}$. The solution is slowly heated to $110^{\circ} \mathrm{C}$ and kept at $110^{\circ} \mathrm{C}$ for $30 \mathrm{~min}$ to remove methanol and the remaining water completely. Then, $0.2 \mathrm{mmol}$ of $\mathrm{NaYF}_{4}$ core nanocrystals in cyclohexane was injected into the reaction solution. After holding the reaction temperature at $110^{\circ} \mathrm{C}$ for further $10 \mathrm{~min}$ to evaporate all cyclohexane, the reaction mixture was quickly heated to $310^{\circ} \mathrm{C}$ and aged for $1 \mathrm{~h}$.

$\mathbf{N a G d F}_{\mathbf{4}} / \mathbf{N a Y F}_{\mathbf{4}} \mathbf{N R s}$ by adding KOH. $\mathrm{GdCl}_{3}(0.2 \mathrm{mmol})$ in $1 \mathrm{ml}$ of methanol solution was magnetically mixed with OA $(9.5 \mathrm{mmol})$ and ODE $(25 \mathrm{mmol})$ in a 50-ml three-neck round-bottom flask. The mixture was degassed under Ar flow and heated to $150^{\circ} \mathrm{C}$ for $30 \mathrm{~min}$ to form a clear solution, before cooling to room temperature. Methanol solution $(5 \mathrm{ml})$ containing $\mathrm{NH}_{4} \mathrm{~F}(0.8 \mathrm{mmol}), \mathrm{KOH}$ $(0.4 \mathrm{mmol})$ and $\mathrm{NaOH}(0.5 \mathrm{mmol})$ was added into the $\mathrm{OA}$ and ODE solution and stirred for $60 \mathrm{~min}$. The solution was slowly heated to $110^{\circ} \mathrm{C}$ and kept at $110^{\circ} \mathrm{C}$ for $30 \mathrm{~min}$ to remove the methanol and water completely. The reaction mix was then injected with $0.2 \mathrm{mmol}$ of $\mathrm{NaYF}_{4}$ core nanocrystals in cyclohexane, into the reaction solution. After holding the reaction mix at $110^{\circ} \mathrm{C}$ for further $10 \mathrm{~min}$ to evaporate all cyclohexane, the mixture was heated rapidly to $310^{\circ} \mathrm{C}$ before aging for $1 \mathrm{~h}$ at this temperature.
$\mathbf{N a Y F}_{4} / \mathrm{NaGdF}_{\mathbf{4}} / \mathrm{NaYF}_{\mathbf{4}} \mathbf{N C s}$ in a bamboo-like shape. $0.2 \mathrm{mmol}$ of $\mathrm{YCl}_{3}$ in $1 \mathrm{ml}$ of methanol solution was magnetically mixed with OA $(9.5 \mathrm{mmol})$ and ODE $(25 \mathrm{mmol})$ in a $50-\mathrm{ml}$ three-neck round-bottom flask. The mixture was degassed under Ar flow and heated to $150^{\circ} \mathrm{C}$ for $30 \mathrm{~min}$ to form a clear solution, and then cooled to room temperature. Methanol solution $(5 \mathrm{ml})$ containing $\mathrm{NH}_{4} \mathrm{~F}$ $(0.8 \mathrm{mmol}), \mathrm{KOH}(0.4 \mathrm{mmol})$ and $\mathrm{NaOH}(0.5 \mathrm{mmol})$ was added into the $\mathrm{OA}$ and ODE solution and stirred for 60 minutes. The solution was slowly heated to $110^{\circ} \mathrm{C}$ and kept at $110^{\circ} \mathrm{C}$ for $30 \mathrm{~min}$ to remove the methanol and water completely. The reaction solution was then injected with $0.2 \mathrm{mmol}$ of $\mathrm{NaYF}_{4} / \mathrm{NaGdF}_{4} \mathrm{NRs}$ in cyclohexane solution. After the reaction at $110^{\circ} \mathrm{C}$ for a further $10 \mathrm{~min}$ to evaporate all the cyclohexane, the reaction mixture was quickly heated to $310^{\circ} \mathrm{C}$ and held at this temperature for $1 \mathrm{~h}$.

$\mathrm{NaYF}_{4} / \mathrm{NaGdF}_{4} / \mathrm{NaYF}_{4} / \mathrm{NaGdF}_{4} \mathbf{N C s}$ in a bamboo-like shape. The same procedure for synthesizing $\mathrm{NaYF}_{4} / \mathrm{NaGdF}_{4} / \mathrm{NaYF}_{4} \mathrm{NCs}$ in bamboo-like shape was repeated, and then followed by the injection of $0.2 \mathrm{mmol}$ of the five-section $\mathrm{NaYF} / \mathrm{NaGdF}_{4} / \mathrm{NaYF}_{4}$ nano-bamboos which acted as the core, all in cyclohexane solution, into the reaction solution. After holding at $110^{\circ} \mathrm{C}$ for a further $10 \mathrm{~min}$ to evaporate all cyclohexane, the reaction mixture was quickly heated to $310^{\circ} \mathrm{C}$ and held again for $1 \mathrm{~h}$.

$\mathbf{N a Y F}_{4} / \mathrm{NaGdF}_{\mathbf{4}} / \mathbf{N a N d F}_{\mathbf{4}} \mathbf{N C s}$ in an hourglass shape. $\mathrm{NdCl}_{3}(0.4 \mathrm{mmol})$ in $2 \mathrm{ml}$ of methanol solution was magnetically mixed with OA $(9.5 \mathrm{mmol})$ and ODE ( $25 \mathrm{mmol})$ in a $50-\mathrm{ml}$ three-neck round-bottom flask. The mixture was degassed under Ar flow and heated to $150^{\circ} \mathrm{C}$ for $30 \mathrm{~min}$ to form a clear solution, and then cooled to room temperature. Methanol solution $(5 \mathrm{ml})$ containing $\mathrm{KOH}(0.8 \mathrm{mmol})$ and $\mathrm{NaOH}(0.8 \mathrm{mmol})$ was added and stirred for $60 \mathrm{~min}$. The solution was slowly heated to $110^{\circ} \mathrm{C}$ and kept at $110^{\circ} \mathrm{C}$ for 30 min to completely remove the methanol and some of the water. It was then injected with $0.1 \mathrm{mmol} 50 \mathrm{~nm} \times 60 \mathrm{~nm}$ $\mathrm{NaYF}_{4} / \mathrm{NaGdF}_{4}$ nano-prisms particles, in a solution of cyclohexane. After having been kept at $110^{\circ} \mathrm{C}$ for another $10 \mathrm{~min}$ to evaporate all cyclohexane, the reaction mixture was quickly heated to $310^{\circ} \mathrm{C}$. Samples $(500 \mathrm{ul})$ of the reaction solution were collected each time with a syringe at 5, 15, 30, 40, 50 and 60 min after the start of the reaction.

Transversal growth of $\mathbf{N a G d F}_{\mathbf{4}}$ shell onto $\mathrm{NaYF}_{\mathbf{4}}$ core. $\mathrm{GdCl}_{3}(0.1 \mathrm{mmol})$ in $1 \mathrm{ml}$ methanol solution was magnetically mixed with OA $(19.0 \mathrm{mmol})$ and ODE $(18.7 \mathrm{mmol})$ in a $50-\mathrm{ml}$ three-neck round-bottom flask. The mixture was degassed under $\mathrm{Ar}$ flow and heated to $150^{\circ} \mathrm{C}$ for $30 \mathrm{~min}$ to form a clear solution, and then cooled to room temperature. Methanol solution $(3 \mathrm{ml})$ containing $\mathrm{NH}_{4} \mathrm{~F}$ $(0.4 \mathrm{mmol})$ and $\mathrm{NaOH}(0.15 \mathrm{mmol})$ was added into the $\mathrm{OA}$ and $\mathrm{ODE}$ solution and stirred for $60 \mathrm{~min}$. The solution was slowly heated to $110^{\circ} \mathrm{C}$ and kept at $110^{\circ} \mathrm{C}$ for $30 \mathrm{~min}$ to remove completely the methanol and water. Then $0.1 \mathrm{mmol}$ of the $\mathrm{NaYF}_{4}$ cores in cyclohexane solvent were injected into the reaction mix. After being kept at $110^{\circ} \mathrm{C}$ for further $10 \mathrm{~min}$ to evaporate all cyclohexane, the reaction mixture was quickly heated up to $290^{\circ} \mathrm{C}$ and held at that temperature for $3 \mathrm{~h}$.

Synthesis of $\mathrm{NaYF}_{\mathbf{4}} / \mathrm{NaGdF}_{\mathbf{4}} / \mathrm{NaNdF}_{\mathbf{4}} \mathbf{N C s}$ in flower shape. $\mathrm{NdCl}_{3}(0.1 \mathrm{mmol})$ in $1 \mathrm{ml}$ of methanol solution was magnetically mixed with OA $(19 \mathrm{mmol})$ and ODE $(18.7 \mathrm{mmol})$ in a $50-\mathrm{ml}$ three-neck round-bottom flask. The mixture was degassed under Ar flow and heated to $150^{\circ} \mathrm{C}$ for $30 \mathrm{~min}$ to form a clear solution, and then cooled to room temperature. Methanol solution $(5 \mathrm{ml})$ containing $\mathrm{NaOH}$ $(0.6 \mathrm{mmol})$ was added and stirred for $60 \mathrm{~min}$. The solution was slowly heated to $110^{\circ} \mathrm{C}$ and kept at $110^{\circ} \mathrm{C}$ for $30 \mathrm{~min}$ to completely remove the methanol and some of the water. Then, the reaction mix was injected with $0.1 \mathrm{mmol}$ of $50 \mathrm{~nm}$ $\mathrm{NaYF}_{4} / \mathrm{NaGdF}_{4}$ nano-prisms prisms $\left(\mathrm{NaGdF}_{4}\right.$ growing on the lateral faces of $\mathrm{NaYF}_{4}$ nanocrystal), suspended in a cyclohexane solution. After holding at $110^{\circ} \mathrm{C}$ for another $10 \mathrm{~min}$ to evaporate all cyclohexane, the reaction mixture was quickly heated to $300^{\circ} \mathrm{C}$. samples $(500 \mathrm{ul})$ of the reaction solution were collected each time with a syringe after 10,25 and $45 \mathrm{~min}$ of the reaction time.

Synthesis of $\mathrm{NaYF}_{4} / \mathrm{NaGdF}_{4} / \mathrm{NaNdF}_{4}$ sharp-end dumbbell. $\mathrm{NdCl}_{3}(0.1 \mathrm{mmol})$ in $1 \mathrm{ml}$ of methanol solution was magnetically mixed with $\mathrm{OA}(9.5 \mathrm{mmol})$ and ODE $(25 \mathrm{mmol})$ in a $50-\mathrm{ml}$ three-neck round-bottom flask. The mixture was degassed under Ar flow and heated to $160^{\circ} \mathrm{C}$ for 30 min to form a clear solution, and then cooled to room temperature. Methanol solution $(5 \mathrm{ml})$ containing $\mathrm{KOH}(0.2 \mathrm{mmol})$ and $\mathrm{NaOH}(0.2 \mathrm{mmol})$ was added and stirred for 60 min. Note: in this reaction no $\mathrm{NH}_{4} \mathrm{~F}$ was added to the solution. The solution was slowly heated to $110^{\circ} \mathrm{C}$ and kept at $110^{\circ} \mathrm{C}$ for $30 \mathrm{~min}$ to remove the methanol and the water completely. It was then injected with $0.1 \mathrm{mmol}$ of $\mathrm{NaYF}_{4} / \mathrm{NaGdF}_{4} \mathrm{NR}$ particle in suspended in cyclohexane solvent into the reaction solution. After holding at $110^{\circ} \mathrm{C}$ for a further $10 \mathrm{~min}$ to evaporate all cyclohexane, the reaction mixture was quickly heated to $310^{\circ} \mathrm{C}$ and held at this temperature for a further $30 \mathrm{~min}$.

Synthesis of $\mathrm{NaYF}_{\mathbf{4}} / \mathrm{NaGdF}_{\mathbf{4}} / \mathrm{NaNdF}_{\mathbf{4}}$ round-end dumbbell. $\mathrm{NdCl}_{3}(0.1 \mathrm{mmol})$ in $1 \mathrm{ml}$ of methanol solution was magnetically mixed with $\mathrm{OA}(9.5 \mathrm{mmol})$ and 
ODE $(25 \mathrm{mmol})$ in a $50-\mathrm{ml}$ three-neck round-bottom flask. The mixture was degassed under Ar flow and heated to $160^{\circ} \mathrm{C}$ for $30 \mathrm{~min}$ to form a clear solution, and then cooled to room temperature. Methanol solution $(5 \mathrm{ml})$ containing $\mathrm{NH}_{4} \mathrm{~F}$ $(0.3 \mathrm{mmol}), \mathrm{KOH}(0.2 \mathrm{mmol})$ and $\mathrm{NaOH}(0.2 \mathrm{mmol})$ was added and the mixture was stirred for $60 \mathrm{~min}$. The solution was slowly heated to $110^{\circ} \mathrm{C}$ and kept at $110^{\circ} \mathrm{C}$ for $30 \mathrm{~min}$ to remove the methanol and the water completely. Then, it was injected with $0.1 \mathrm{mmol}$ of $\mathrm{NaYF}_{4} / \mathrm{NaGdF}_{4} \mathrm{NRs}$ suspended in cyclohexane into the reaction solution. After being held at $110^{\circ} \mathrm{C}$ for further $10 \mathrm{~min}$ to evaporate all cyclohexane, the reaction mixture was quickly heated to $310^{\circ} \mathrm{C}$ and held for $30 \mathrm{~min}$ at this temperature.

Synthesis of pure $\alpha-\mathbf{N a G d F}_{\mathbf{4}} \mathbf{N C s}$. Methanol solution $(2 \mathrm{ml})$ of $\mathrm{GdCl}_{3}(1.0 \mathrm{mmol})$ was magnetically mixed with OA $(19 \mathrm{mmol})$ and ODE $(47 \mathrm{mmol})$ in a $100-\mathrm{ml}$ three-neck round-bottom flask. The mixture was degassed under Ar flow and heated to $150{ }^{\circ} \mathrm{C}$ for 30 minutes to form a clear solution, and then cooled to room temperature. Methanol solution $(10 \mathrm{ml})$ containing $\mathrm{NH}_{4} \mathrm{~F}(4 \mathrm{mmol})$ and $\mathrm{NaOH}$ $(2.5 \mathrm{mmol})$ was added and stirred for $60 \mathrm{~min}$. Then, the solution was slowly heated to $110^{\circ} \mathrm{C}$ and kept at $110^{\circ} \mathrm{C}$ for $30 \mathrm{~min}$ to remove the methanol and water completely. After that, the reaction mixture was quickly heated to $240{ }^{\circ} \mathrm{C}$ and aged for $45 \mathrm{~min}$.

Synthesis of $\mathbf{N a L u F}_{\mathbf{4}} / \mathrm{NaYF}_{\mathbf{4}} \mathbf{N R s} . \mathrm{LuCl}_{3}(0.1 \mathrm{mmol})$ in $1 \mathrm{ml}$ method solution was magnetically mixed with OA $(19 \mathrm{mmol})$ and ODE $(25 \mathrm{mmol})$ in a $50-\mathrm{ml}$ threeneck round-bottom flask. The mixture was degassed under Ar flow and heated to $150{ }^{\circ} \mathrm{C}$ for $30 \mathrm{~min}$ to form a clear solution, and then cooled to room temperature. Methanol solution $(2 \mathrm{ml})$ containing $\mathrm{NaOH}(0.15 \mathrm{mmol})$ and $0.4 \mathrm{mmol} \mathrm{NH}_{4} \mathrm{~F}$ was added and stirred for $60 \mathrm{~min}$. The solution was slowly heated to $110^{\circ} \mathrm{C}$ and kept at $110^{\circ} \mathrm{C}$ for $30 \mathrm{~min}$ to completely remove the methanol and some of the water. It was then injected with $0.4 \mathrm{mmol}$ of $\mathrm{NaYF}_{4}$ seed particles in a cyclohexane solution. After holding the reaction mix at $110^{\circ} \mathrm{C}$ for a further $10 \mathrm{~min}$ to evaporate cyclohexane, the reaction mixture was quickly heated to $290^{\circ} \mathrm{C}$ and held at that temperature for a further $1 \mathrm{~h}$.

Synthesis of $\mathbf{N a L u F}_{\mathbf{4}} / \mathbf{N a Y F}_{\mathbf{4}} \mathbf{N R s}$ with $\mathbf{N a G d F}_{\mathbf{4}}$ double-ring. $\mathrm{GdCl}_{3}(0.1 \mathrm{mmol})$ in $1 \mathrm{ml}$ methanol solution was magnetically mixed with OA $(19.0 \mathrm{mmol})$ and ODE $(18.7 \mathrm{mmol})$ in a $50-\mathrm{ml}$ three-neck round-bottom flask. The mixture was degassed under Ar flow and heated to $150{ }^{\circ} \mathrm{C}$ for $30 \mathrm{~min}$ to form a clear solution, and then cooled to room temperature. Methanol solution $(2 \mathrm{ml})$ containing $\mathrm{NaOH}$ (at $0.15 \mathrm{mmol}$ ) was added and stirred for $60 \mathrm{~min}$. The solution was slowly heated to $110^{\circ} \mathrm{C}$ and kept at $110^{\circ} \mathrm{C}$ for $30 \mathrm{~min}$ to completely remove the methanol and some of the water. It was then injected with $0.1 \mathrm{mmol}$ of the $\mathrm{NaYF}_{4} / \mathrm{NaLuF}_{4}$ seed particles, in a cyclohexane solution, into the reaction solution. After having been held the reaction mix at $110^{\circ} \mathrm{C}$ for another $10 \mathrm{~min}$ to evaporate cyclohexane, the reaction mixture was quickly heated to $300^{\circ} \mathrm{C}$. It was then, injected with $0.02 \mathrm{mmol}$ of $\alpha-\mathrm{NaGdF}_{4}$ nanocrystals into the reaction system. This was done every $10 \mathrm{~min}$ for 5 times at $300^{\circ} \mathrm{C}$. The reaction mix was held at this temperature for another $10 \mathrm{~min}$ after the last injection.

\section{References}

1. Jia, G. H. et al. Couples of colloidal semiconductor nanorods formed by self-limited assembly. Nat. Mater. 13, 302-308 (2014).

2. Jones, M. R., Seeman, N. C. \& Mirkin, C. A. Programmable materials and the nature of the DNA bond. Science 347, 1260901 (2015).

3. Ye, X. et al. Seeded growth of metal-doped plasmonic oxide heterodimer nanocrystals and their chemical transformation. J. Am. Chem. Soc. 136, 5106-5115 (2014).

4. $\mathrm{Yu}, \mathrm{H}$. et al. Dumbbell-like bifunctional Au-Fe3O4 nanoparticles. Nano Lett. 5, 379-382 (2005).

5. Jun, Y. W., Choi, J. S. \& Cheon, J. Shape control of semiconductor and metal oxide nanocrystals through nonhydrolytic colloidal routes. Angew. Chem. Int. Ed. 45, 3414-3439 (2006).

6. Hill, J. P. et al. Self-assembled hexa-peri-hexabenzocoronene graphitic nanotube. Science 304, 1481-1483 (2004).

7. Yin, Y. \& Alivisatos, A. P. Colloidal nanocrystal synthesis and the organic-inorganic interface. Nature 437, 664-670 (2005)

8. Zeng, H. \& Sun, S. H. Syntheses, properties and potential applications of multicomponent magnetic nanoparticles. Adv. Funct. Mater. 18, 391-400 (2008).

9. Qian, H. F., Zhu, Y. \& Jin, R. C. Atomically precise gold nanocrystal molecules with surface plasmon resonance. Proc. Natl Acad. Sci. USA 109, 696-700 (2012).

10. Zheng, W. et al. Lanthanide-doped upconversion nano-bioprobes: electronic structures, optical properties, and biodetection. Chem. Soc. Rev. 44, 1379-1415 (2015).

11. Wang, X., Zhuang, J., Peng, Q. \& Li, Y. D. A general strategy for nanocrystal synthesis. Nature 437, 121-124 (2005)

12. Wang, F. et al. Simultaneous phase and size control of upconversion nanocrystals through lanthanide doping. Nature 463, 1061-1065 (2010).
13. Deng, R. et al. Temporal full-colour tuning through non-steady-state upconversion. Nat. Nanotechnol. 10, 237-242 (2015).

14. Ramasamy, P. \& Kim, J. Combined plasmonic and upconversion rear reflectors for efficient dye-sensitized solar cells. Chem. Commun. 50, 879-881 (2014).

15. Lu, Y. Q. et al. Tunable lifetime multiplexing using luminescent nanocrystals. Nat. Photon. 8, 33-37 (2014).

16. Wang, J. et al. Near-infrared-light-mediated imaging of latent fingerprints based on molecular recognition. Angew. Chem. 126, 1642-1646 (2014).

17. Huang, P. et al. Lanthanide-doped $\mathrm{LiLuF}_{4}$ upconversion nanoprobes for the detection of disease biomarkers. Angew. Chem. Int. Ed. 53, 1252-1257 (2014).

18. Zhao, J. et al. Single-nanocrystal sensitivity achieved by enhanced upconversion luminescence. Nat. Nanotechnol. 8, 729-734 (2013).

19. Gargas, D. J. et al. Engineering bright sub-10-nm upconverting nanocrystals for single-molecule imaging. Nat. Nanotechnol. 9, 300-305 (2014).

20. Liu, Q. et al. F-18-labeled magnetic-upconversion nanophosphors via rare-earth cation-assisted ligand assembly. ACS Nano 5, 3146-3157 (2011).

21. Idris, N. M. et al. In vivo photodynamic therapy using upconversion nanoparticles as remote-controlled nanotransducers. Nat. Med. 18, 1580-1585 (2012).

22. Wang, C., Cheng, L. \& Liu, Z. Upconversion nanoparticles for photodynamic therapy and other cancer therapeutics. Theranostics 3, 317-330 (2013).

23. Kang, X. J. et al. Lanthanide-doped hollow nanomaterials as theranostic agents. Wiley Interdiscip. Rev. Nanomed. Nanobiotechnol. 6, 80-101 (2014).

24. Mai, H. X., Zhang, Y. W., Sun, L. D. \& Yan, C. H. Highly efficient multicolor up-conversion emissions and their mechanisms of monodisperse $\mathrm{NaYF}_{4}$ : $\mathrm{Yb}, \mathrm{Er}$ core and core/shell-structured nanocrystals. J. Phys. Chem. C 111, 13721-13729 (2007).

25. Shen, J. et al. Tunable near infrared to ultraviolet upconversion luminescence enhancement in (alpha-NaYF4:Yb,Tm)/CaF2 core/shell nanoparticles for in situ real-time recorded biocompatible photoactivation. Small 9, 3213-3217 (2013).

26. Wen, H. et al. Upconverting near-infrared light through energy management in core-shell-shell nanoparticles. Angew. Chem. Int. Ed. 52, 13419-13423 (2013).

27. Johnson, N. J. \& van Veggel, F. C. Lanthanide-based hetero-epitaxial core-shell nanostructures: the compressive vs. tensile strain asymmetry. ACS Nano 8, 10517-10527 (2014).

28. Zhang, C. \& Lee, J. Y. Prevalence of anisotropic shell growth in rare earth core-shell upconversion nanocrystals. ACS Nano 7, 4393-4402 (2013).

29. Johnson, N. J. J. \& van Veggel, F. C. J. M. Sodium lanthanide fluoride core-shell nanocrystals: a general perspective on epitaxial shell growth. Nano Res. 6, 547-561 (2013).

30. Xia, Y., Xiong, Y., Lim, B. \& Skrabalak, S. E. Shape-controlled synthesis of metal nanocrystals: simple chemistry meets complex physics? Angew. Chem. Int. Ed. 48, 60-103 (2009).

31. Zhuang, Z., Peng, Q. \& Li, Y. Controlled synthesis of semiconductor nanostructures in the liquid phase. Chem. Soc. Rev. 40, 5492-5513 (2011).

32. Wang, F., Deng, R. R. \& Liu, X. G. Preparation of core-shell $\mathrm{NaGdF}_{4}$ nanoparticles doped with luminescent lanthanide ions to be used as upconversion-based probes. Nat. Protoc. 9, 1634-1644 (2014).

33. Zherebetskyy, D. et al. Hydroxylation of the surface of PbS nanocrystals passivated with oleic acid. Science 344, 1380-1384 (2014).

34. Bealing, C. R., Baumgardner, W. J., Choi, J. J., Hanrath, T. \& Hennig, R. G. Predicting nanocrystal shape through consideration of surface-ligand interactions. ACS Nano 6, 2118-2127 (2012).

35. Clark, S. J. et al. First principles methods using CASTEP. Z. Kristallogr. 220, 567-570 (2005).

36. Sui, Y. Q., Tao, K., Tian, Q. \& Sun, K. Interaction between $\mathrm{Y}^{3+}$ and oleate ions for the cubic-to-hexagonal phase transformation of NaYF4 nanocrystais. J. Phys. Chem. C 116, 1732-1739 (2012).

37. Yi, G. et al. Synthesis, characterization, and biological application of size-controlled nanocrystalline $\mathrm{NaYF}_{4}$ : $\mathrm{Yb}$, Er infrared-to-visible up-conversion phosphors. Nano Lett. 4, 2191-2196 (2004).

38. Xia, A. et al. $\mathrm{Gd}^{3}+$ complex-modified $\mathrm{NaLuF}_{4}$-based upconversion nanophosphors for trimodality imaging of NIR-to-NIR upconversion luminescence, $\mathrm{X}$-Ray computed tomography and magnetic resonance. Biomaterials 33, 5394-5405 (2012).

39. Hou, Y. et al. $\mathrm{NaGdF}_{4}$ nanoparticle-based molecular probes for magnetic resonance imaging of intraperitoneal tumor xenografts in vivo. ACS Nano 7, 330-338 (2012).

\section{Acknowledgements}

We thank D. Birch in Microscope Unit at Macquarie University and D.R.G. Mitchell in Electron Microscopy Centre at the University of Wollongong for their help and valuable discussion on transmission electron microscope characterizations. This project is primarily supported by the Australian Research Council (ARC) Future Fellowship Scheme (FT 130100517; D.J.), ARC Centre of Excellence Scheme through Centre for Nanoscale BioPhotonics, Macquarie University Research Fellowship Scheme (X.X.), ARC LIEF grant (LE120100104, Y.D.), ARC Discovery Project (DP140102581, Y.D.), China 
Scholarship Council CSC scholarships (no.201206170136, D.L., C.M.) and the Agency for Science, Technology and Research (A ${ }^{\star}$ STAR; grant no. 1231AFG028, X.L.).

\section{Author contributions}

D.J. and X.L. conceived the project and supervised the research; X.X., D.L., D.J. and X.L. designed the experiments; D.L., C.M., Y.Z. and S.W. conducted synthesis; X.Q. and X.X. conducted crystallography analysis and computational modelling; D.L., Y.D., S.D., W.R. and X.X. conducted characterizations and analysis; D.L., X.X., X.Q. and Y.Z. prepared figures and supplementary information sections; D.J., D.L., X.X., E.M.G., X.Qin. and $\mathrm{X}$. Liu wrote the manuscript. All authors contributed to data analysis, discussions and manuscript preparation.

\section{Additional information}

Supplementary Information accompanies this paper at http://www.nature.com/ naturecommunications
Competing financial interests: The authors declare no competing financial interests.

Reprints and permission information is available online at http://npg.nature.com/ reprintsandpermissions/

How to cite this article: Liu, D. et al. Three-dimensional controlled growth of monodisperse sub-50 nm heterogeneous nanocrystals. Nat. Commun. 7:10254 doi: 10.1038/ncomms10254 (2016).

(c) (i) This work is licensed under a Creative Commons Attribution 4.0 International License. The images or other third party material in this article are included in the article's Creative Commons license, unless indicated otherwise in the credit line; if the material is not included under the Creative Commons license, users will need to obtain permission from the license holder to reproduce the material. To view a copy of this license, visit http://creativecommons.org/licenses/by/4.0/ 